\title{
Study experimental alat destilasi air laut terhadap kuantitas dan kualitas air tawar yang dihasilkan dengan menggunakan energi matahari
}

\author{
Ahmad Yani \\ Jurusan Teknik Mesin Sekolah Tinggi Teknologi Industri Bontang \\ Jl. Brigjend Katamso No. 40 Bontang - Kaltim \\ ${ }^{*}$ Corresponding author: yanibima@gmail.com
}

\begin{abstract}
One of the benefits of sunlight is to evaporate water (distillation). The working principle of this tool is that solar radiation penetrates the glass cover and hits the surface of the absorber, so that it turns into heat energy. The heat energy from the absorber is absorbed by the plate and seawater in the container in the distillation apparatus causes evaporation to occur. The water vapor produced will move up and stick to the bottom surface of the glass cover. The heat transferred to the environment causes water vapor that has reached the saturation temperature to condense. The dew that sticks to the inner surface of the glass cover will fall down by gravity following the slope of the glass cover on the outlet pipe. The purpose of this study was to determine the quantity and quality of fresh water produced by distillation equipment using solar energy. The research was conducted using an experimental method with an experimental design of a seawater distillation apparatus. The results showed that the quantity of distilled water produced from 07:00 to 16:00 for 8 days was $2578 \mathrm{ml}$. The quality of fresh water produced from the distillation apparatus includes turbidity, color, dissolved solids, temperature, taste, and odor that has met the requirements for use by the community in daily life based on the regulation of the Minister of Health of the Republic of Indonesia number 32 of 2017 concerning health quality standards. environmental and water health requirements for sanitary hygiene purposes.
\end{abstract}

Keywords: Distillation, Sea water, quantity, quality and solar energy.

\begin{abstract}
Abstrak
Salah satu manfaat dari sinar matahari adalah menguapkan air (destilasi). Adapun prinsip kerja alat ini adalah radiasi matahari menembus glass cover dan mengenai permukaan absorber, sehingga berubah menjadi energi panas. Energi panas dari absorber diserap oleh plat dan air laut pada wadah penampung pada alat destilasi menyebabkan terjadi penguapan. Uap air yang dihasilkan akan bergerak ke atas dan menempel pada permukaan bawah glass cover. Adanya kalor yang dipindahkan ke lingkungan menyebabkan uap air yang telah mencapai temperatur jenuh mengembun. Embun yang menempel pada permukaan glass cover bagian dalam akan turun secara grafitas mengikuti kemiringan glass cover pada pipa keluar. Tujuan penelitian ini untuk mengetahui kuantitas dan kualitas air tawar yang dihasilkan alat destilasi dengan menggunakan energi matahari. Penelitian yang dilakukan menggunakan metode eksperimental dengan rancangan percobaan alat destilasi air laut. Hasil penelitian menunjukkan kuantitas air destilasi yang dihasilkan mulai dari jam 07:00 sampai jam 16:00 selama 8 hari sebesar $2578 \mathrm{ml}$. Kualitas air tawar yang dihasilkan dari alat destilasi mencangkup Kekeruhan, warna, zat padat terlarut, suhu, rasa, dan bau telah memenuhi syarat untuk digunakan oleh masyarakat dalam kehidupan sehari-hari berdasarkan peraturan menteri kesehatan Republik Indonesia nomor 32 Tahun 2017 tentang standar baku mutu kesehatan lingkungan dan persyaratan kesehatan air untuk keperluan higiene sanitasi.
\end{abstract}


Kata Kunci: Destilasi, Air laut, kuantitas, kualitas dan energi matahari.

\section{Pendahuluan}

Hampir 97\% air di muka bumi ini merupakan air laut dan tidak dapat digunakan oleh manusia secara langsung. Dari $3 \%$ yang tersisa, $2 \%$ diantaranya tersimpan sebagai gunung es (gletser) di kutub yang juga tidak dapat dimanfaatkan secara langsung. Hanya $1 \%$ air yang terdapat di danau, sungai dan air tanah yang benarbenar tersedia bagi keperluan manusia [1]. Kondisi daerah wilayah Indonesia yang terdiri dari pulau-pulau dengan wilayah laut yang sangat luas, dimana masih banyak daerah - daerah yang kekurangan air bersih khsusnya air minum untuk kebutuhan sehari-hari. Salah satu contoh di daerah Bontang khususnya pada daerah kepulauan yang tidak bisa disuplai oleh PDAM sehingga masyarakat sangat susah mendapatkan air tawar untuk kebutuhan sehari-hari. Ketersediaan air bersih merupakan barang langkah dan merupakan masalah utama di daerah-daerah pesisir kota Bontang.

Salah satu cara untuk mendapatkan air tawar adalah dengan memanfaatkan sumber air yang ada yaitu air laut [2]. Salinitas yang terkandung air laut sebesar 35 , sehingga setiap satu liter air laut terdapat 35 gram kandungan garam [3]. Sehingga dengan jumlah salinitas tersebut tentu tidak bisa dikonsumsi dan supaya dapat dimanfaatkan, maka air laut perlu diproses untuk menjadikan air tawar dengan kadar garamnya di bawah 0,5 ppt [4]. dengan cara memanfaatkan panas matahari sebagai alternatif melakukan destilasi (penyulingan) air laut tersebut [5].

Salah satu manfaat dari sinar matahari adalah menguapkan air (destilasi). Adapun prinsip kerja alat ini adalah radiasi matahari menembus glass cover dan mengenai permukaan absorber, sehingga berubah menjadi energi panas. Energi panas dari absorber diserap oleh plat dan air laut pada wadah penampung pada alat destilasi menyebabkan terjadi penguapan. Uap air yang dihasilkan akan bergerak ke atas dan menempel pada permukaan bawah glass cover. Adanya kalor yang dipindahkan ke lingkungan menyebabkan uap air yang telah mencapai temperatur jenuh mengembun. Embun yang menempel pada permukaan glass cover bagian dalam akan turun secara grafitas mengikuti kemiringan glass cover pada pipa keluar [6].

Tujuan penelitian ini yaitu untuk mengolah air laut menjadi air tawar dengan mengetahui kuantitas dan kuantitas air tawar yang dihasilkan alat destilasi dengan menggunakan energi matahari.

\section{Metoda Penelitian}

Sistem destilasi menggunakan energi matahari ini cukup sederhana, mudah dibuat dan biayanya relative murah dengan cara kerja pengolahanya menguapkan air laut yang ada pada bak detilasi sehingga kotoran pada air laut tersebut menjadi terpisah, yang akhirnya didapatkan air tawar yang bersih [7].

\section{Jenis Penelitian}

Jenis penelitian ini merupakan penelitian lapangan dimana penelitian ini dilakukan dengan cara eksperimental menggunakan prototype destilasi air laut. Penelitian ini dilaksanakan pada pemukiman warga yang tinggal di atas laut daerah Bontang Kuala - Kota Bontang Kalimantan Timur.

\section{Bahan dan Alat Penelitian}

Bahan yang digunakan pada penelitian ini diantaranya:

1. Air laut, sebagai bahan dasar untuk dirubah menjadi air tawar.

2. Besi plat siku, digunakan untuk membuat rangka alat destilasi

3. Plat seng, digunakan untuk membuat bak penampung air laut, dan saluran air tawar dari hasil destilasi air laut, serta sebagai penyerap panas.

4. Kaca, digunakan untuk atap destilasi.

5. Engsel, digunakan untuk membuka kaca atap destilasi.

6. Botol aqua, digunakan untuk menampung hasil air destilasi. 
Alat yang digunakan pada penelitian ini:

1. Prototype destilasi air laut

Salah satu alat utama yang sangat penting untuk penelitian ini yaitu sebuah prototype destilasi air laut yang penulis buat dengan ukuran atap destilasi $150 \mathrm{~cm} \mathrm{X} 80$ $\mathrm{cm}$ X $70 \mathrm{~cm}$ dan dimensi untuk bak destilasi $150 \mathrm{~cm} \mathrm{X} 80 \mathrm{~cm} \mathrm{X} 25 \mathrm{~cm}$. Hasil dari pembuatan alat destilasi yang menjadi objek penelitian penulis seperti ditunjukkan pada gambar 1 .

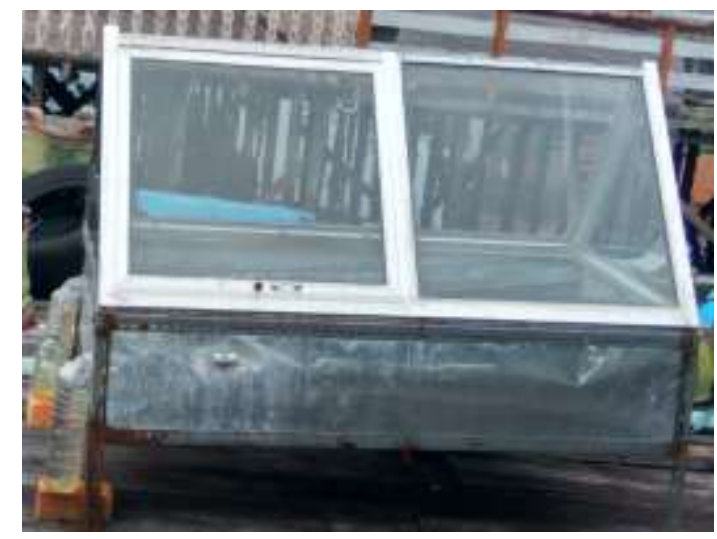

Gambar 1. Dokumentasi alat penelitian

2. Thermometer analog dan digital, digunakan sebagi pengukur Temperatur udara luar (suhu lingkungan), Temperatur permukaan kolektor luar (kaca pada bagian luar), Temperatur ruang kolektor dalam (kaca pada bagian dalam), dan Temperatur plat.

3. Jam, digunakan untuk menghitung waktu per jam pengambilan data.

4. Gelas ukur, digunakan untuk mengukur volume/kuantitas air hasil destilasi.

5. Alat tulis, digunakan untuk mencatat hasil data penelitian di lapangan.

6. Las listrik, digunakan untuk menyambungkan plat siku rangka destilasi.

7. Gunting plat, digunakan untuk menggunting lembaran plat sesui ukuran yang akan dibuat.

\section{Prosedur Pelaksanaan Penelitian}

Pengerjaan alat penelitian ini disusun dalam beberapa tahap yang mencangkup perencanaan dan pola pelaksanaan kerja. Perancangan model dilakukan berupa pengujian desain dalam bentuk prototype dan selanjutnya dilakukan ujicoba kinerja prototype alat destilasi. Adapun prosedur pelaksanaan penelitian yang dilakukan antara lain:

1. Persiapan alat dan bahan

2. Proses pengambilan data atau pengujian alat destilasi yang meliputi:

a. Menyiapkan alat tulis untuk mencatat hasil pengambilan data pengukuran.

b. Menyiapkan alat destilasi air laut yang telah di buat.

c. Mengisi air laut kedalam wadah atau bak destilasi.

d. Meletakan plat seng kedalam bak destilasi untuk menyerap panas matahari.

e. Alat destilasi beroperasi dari pukul 07.00 - 16.00 Wita, setiap per satu jam dilakukan pengkuran diantaranya:

1. Temperatur udara luar (suhu lingkungan).

2. Temperatur ruang kolektor dalam (kaca pada bagian dalam).

3. Temperatur plat.

f. Melakukan pengukuran volume air tawar yang dihasilkan dengan menggunakan gelas ukur sesuai dengan waktu yang ditentukan untuk mengetahui kuantitas air destilasi.

g. Melakukan pengujian laboratorium hasil air destilasi untuk mengetahui kandungan air hasil destilasi (kualitas air destilasi).

h. Menarik kesimpulan dari hasil penelitian lapangan.

\section{Hasil dan Pembahasan}

Sebelum mejelaskan hasil penelitian yang penulis lakukan, terlebih dahulu penulis memaparkan hasil penelitian sebelumnya untuk membandingkan penelitian penulis dengan penelitian sebelumnya. Perbedaan yang sangat signifikan penelitian ini dengan penelitian sebelumnya yaitu pada penelitian ini dilakukan pengujian kualitas air tawar secara komprehensif yang dihasilkan alat destilasi, diantaranya untuk mengetahui kadar $\mathrm{pH}$, condutifity, turbidity, TDS, 
Cloride, total iron, warna, bau, dan rasa. Sedangkan penelitian sebelumnya tidak melakukan uji kualitas air yang dihasilkan, melainkan hanya melihat warna air, rasa air dan mengetahui volume air tawar dan volume garam yang dihasilkan dari alat destilasi air laut.

Ada beberapa penelitian sebelumnya yang telah dilakukan untuk mengolah air laut menjadi air tawar menggunakan energi matahari antara lain: dilakukan oleh Hidayat membuat alat destilasi menggunakan energi matahari dengan luas kolektor $220 \times 120 \times 5 \mathrm{~cm}^{2}$ dan sudut kemiringan kolektor $40^{\circ}$ [8]. Ismail melakukan penelitian dengan membandingkan bentuk cover satu kemiringan dengan sudut $35^{\circ}$ dan cover bentuk atap dengan luas penampang yang sama, hasil yang diperoleh cover dengan satu kemiringan menghasilkan produktivitas air kondensat lebih tinggi [9]. Putra melakukan penelitian destilasi bentuk atap dibuat dari bahan akrilik transparan dengan kemiringan $45^{\circ}$ [2]. Hasil penelitian yang telah dilakukan Yogi dalam waktu satu hari dapat menghasilkan air tawar maksimum $311,5 \mathrm{ml}$ dan kinerja alat masih rendah dengan efisiensi maksimal 4,45\% [10]. Penelitian dilakukan oleh Kumar, menghasilkan efisiensi solar still $24,47 \%$ tanpa arang, 30,05\% tingkat dengan arang, $11.92 \%$ dengan cermin dan $14.11 \%$ dengan cermin dan arang. Menggunakan cover model atap atau dua sisi dapat meningkatkan produktifitas dan efisiensi solar still [11]. Penelitian dilakukan oleh Mulyanef, ddk menggunakan tipe atap dengan kolektor plat datar dengan hasil pengujian menunjukkan bahwa dari 28 liter air laut yang diproses di dalam kolektor plat datar seluas $(1,20 \mathrm{x}$ 2,00) $\mathrm{m}^{2}$ dapat menghasilkan air tawar sebanyak 2.012 mili liter per hari [12]. Penelitian alat destilasi air laut menggunakan tipe atap dengan menggunakan energi surya yang dilakukan Ali \& Waliden dengan kapasitas air laut $30.000 \mathrm{~mL}$ dilakukan selama 6 jam menghasilkan $1900 \mathrm{~mL}$ air bersih dan 18,2 gram garam [13].
Pada penelitian ini dilakukan pengujian terhadap alat destilasi air laut sehingga diperoleh data penelitian dilapangan seperti ditunjukkan pada tabel 1 .

Tabel 1: Data penelitian dilapangan

\begin{tabular}{|c|c|c|c|c|}
\hline $\begin{array}{c}\text { Waktu } \\
\text { Pengam } \\
\text { bilan } \\
\text { Data }\end{array}$ & $\begin{array}{c}\text { Temper } \\
\text { atur } \\
\text { didalam } \\
\text { ruangan }\end{array}$ & $\begin{array}{c}\text { Temper } \\
\text { atur } \\
\text { lingkun } \\
\text { gan }\end{array}$ & $\begin{array}{c}\text { Luas } \\
\text { permuka } \\
\text { an } \\
\text { plat/abso } \\
\text { rber }\end{array}$ & $\begin{array}{c}\text { Volu } \\
\text { me air } \\
\text { Tawar } \\
\text { Hasil } \\
\text { Destil } \\
\text { asi }\end{array}$ \\
\hline $\begin{array}{l}\text { (Tgl- } \\
\text { Bln- } \\
\text { Thn) }\end{array}$ & $\left(\mathrm{T}_{\mathrm{r}}\right)^{\mathrm{O}} \mathrm{C}$ & $\left(\mathrm{T}_{1}\right)^{\mathrm{O}} \mathrm{C}$ & (A) $\mathrm{m}$ & $\begin{array}{l}\text { (V) } \\
\mathrm{ml}\end{array}$ \\
\hline $15-2-20$ & 34.8 & 24.4 & 1.2 & 390 \\
\hline $16-2-20$ & 38.3 & 25.6 & 1.2 & 230 \\
\hline $17-2-20$ & 41 & 27.1 & 1.2 & 238 \\
\hline $18-2-20$ & 36 & 25.8 & 1.2 & 142 \\
\hline $20-2-20$ & 41 & 26.6 & 1.2 & 450 \\
\hline $22-2-20$ & 36,5 & 26.7 & 1.2 & 241 \\
\hline $23-2-20$ & 39,3 & 26.7 & 1.2 & 300 \\
\hline $24-2-20$ & 41,5 & 27.6 & 1.2 & 587 \\
\hline
\end{tabular}

\section{Kuantitas Air Hasil Destilasi}

Kuantitas atau volume air destilasi yang dihasilkan pada alat penelitian ini mulai dari jam 07:00 sampai jam 16:00 selama 8 hari seperti ditunjukkan pada tabel 1 dan sebagaimana ditunjukkan pada gambar 2.

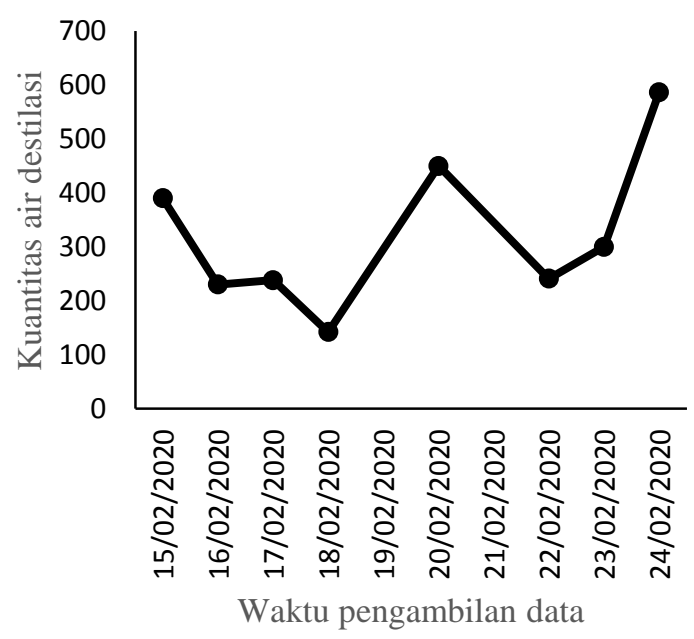

Gambar 2. Kuantitas air hasil destilasi

Berdasarkan dari beberapa pengambilan data dengan hari yang berbeda dapat disimpulkan bahwa kuantitas air hasil destilasi berpengaruh terhadap intensitas radiasi matahari pada saat penelitian. Kuantitas air hasil destilasi ditentukan oleh 
proses penguapan air laut dalam ruangan alat destilasi/evaporasi dan proses pengembunan yang terjadi dikaca penutup. Temperatur air laut yang ada pada bak detilasi mempengaruhi proses pengupan air laut, karena proses perpindahan massa dari zat cair menjadi zat gas (penguapan) itu terjadi karena tumbukan akibat pergerakkan antar molekul dilalamnya yang begitu cepat yang disebabkan temperature semakin tinggi. Hal ini mengakibatkan perubahan berat jenis air dalam bentuk cair menjadi bentuk uap basah menjadi menurun berat jenisnya. Sehingga berbagai impurities yang memiliki berat jenis yang lebih besar dari berat jenis uap akan menjadi residu pada bak destilasi.

Jika dilihat secara keseluruhan dari gambar 2 dapat disimpulkan bahwa kuantitas air yang terbesar terjadi pada pengambilan data hari ke delapan atau pada tanggal 24 Februari 2020 dengan kuantitas/volume air sebesar $587 \mathrm{ml}$, hal ini terjadi karena kondisi intensitas radiasi matahari pada saat itu lebih meningkat dibandingkan dengan hari pengambilan data yang lain. Selanjutnya kuantitas air hasil destilasi yang kedua terjadi pada tanggal 20 Februari 2020 dengan nilai $450 \mathrm{ml}$, kuantitas air hasil destilasi yang ketiga terjadi pada tanggal 15 Februari 2020 dengan nilai 390 $\mathrm{ml}$ dan kuantitas air hasil destilasi terendah terjadi pada tanggal 18 Februari 2020 dengan nilai $142 \mathrm{ml}$. Total keseluruhan volume air tawar yang dihasilkan alat destilasi selama delapan hari pengujian sebesar $2578 \mathrm{ml}$.

\section{Kualitas Air Hasil Destilasi}

Kualitas air tawar yang dihasilkan alat destilasi harus memenuhi standar kesehatan untuk mencegah bahaya kesehatan bagi manusia, karena didalam air mengandung unsur-unsur yang membahayakan jika kadarnya melebihi standar persyaratan yang ditetapkan seperti ditunjukkan tabel 3 dan untuk mengetahui kandungan air hasil destilasi penulis menguji sampel air tersebut di laboratorium dengan hasilnya seperti ditunjukkan pada tabel 2, kemudian hasil air destilasi dibandingkan dengan control range untuk kelayakan kualitas air hasil destilasi tersebut sehingga dapat digunakan oleh masyarakat dalam kehidupan sehari-hari. Penulis membandingkan air hasil destilasi yang diteliti penulis berdasarkan data terbaru yaitu Peraturan menteri kesehatan republik indonesia nomor 32 tahun 2017 tentang standar baku mutu kesehatan lingkungan dan persyaratan kesehatan air untuk keperluan higiene sanitasi [14].

Tabel 2. Data air tawar hasil laboratorium

\begin{tabular}{cccc}
\hline No & $\begin{array}{c}\text { Parameter } \\
\text { yang diuji }\end{array}$ & $\begin{array}{c}\text { Hasil } \\
\text { pengujian } \\
\text { air tawar }\end{array}$ & Unit \\
\hline 1 & $\mathrm{pH}$ & 6.52 & $\mathrm{mg} / \mathrm{L}$ \\
\hline 2 & Condutifity & 259.6 & $\mathrm{NTU}$ \\
\hline 3 & Turbidity & 1 & $\mathrm{mg} / \mathrm{L}$ \\
\hline 4 & TDS & 530 & $\mathrm{mg} / \mathrm{L}$ \\
\hline 5 & Cloride & 64 & $\mathrm{mg} / \mathrm{L}$ \\
\hline 6 & Total Iron & 0.25 & $\mathrm{mg} / \mathrm{L}$ \\
\hline 7 & Warna & $\begin{array}{c}\text { Tidak } \\
\text { berwarna }\end{array}$ & - \\
\hline 8 & Bau & $\begin{array}{c}\text { Tidak } \\
\text { berbau }\end{array}$ & - \\
\hline 9 & Rasa & $\begin{array}{c}\text { Tidak } \\
\text { berasa }\end{array}$ & - \\
\hline
\end{tabular}

Adapun data perbandingan parameter air hasil destilasi dengan control range/standar acuan menurut permenkes $\mathrm{RI}$ No. 32 Tahun 2017 seperti ditunjukkan pada tabel 3 .

Tabel 3. Data perbandingan parameter air destilasi hasil pengujian laboratorium dengan control range

\begin{tabular}{ccccc}
\hline No & Parameter & Result & $\begin{array}{c}\text { Control } \\
\text { Range }\end{array}$ & Unit \\
\hline 1 & $\mathrm{pH}$ & 6,52 & $6,5-8,5$ & $\mathrm{mg} / \mathrm{L}$ \\
\hline 2 & Condutifity & 259,6 & 178 & $\mathrm{NTU}$ \\
\hline 3 & Turbidity & 1 & 25 & $\mathrm{mg} / \mathrm{L}$ \\
\hline 4 & TDS & 530 & 1000 & $\mathrm{mg} / \mathrm{L}$ \\
\hline 5 & Cloride & 64 & 600 & $\mathrm{mg} / \mathrm{L}$ \\
\hline 6 & Total Iron & 0,25 & 1 & $\mathrm{mg} / \mathrm{L}$ \\
\hline 7 & Warna & $\begin{array}{c}\text { Tidak } \\
\text { berwarna }\end{array}$ & $\begin{array}{c}\text { Tidak } \\
\text { berwarna }\end{array}$ & - \\
\hline 8 & Bau & $\begin{array}{c}\text { Tidak } \\
\text { berbau }\end{array}$ & $\begin{array}{c}\text { Tidak } \\
\text { berbau }\end{array}$ & - \\
\hline 9 & Rasa & $\begin{array}{c}\text { Tidak } \\
\text { berasa }\end{array}$ & $\begin{array}{c}\text { Tidak } \\
\text { berasa }\end{array}$ & - \\
\hline
\end{tabular}




\section{Kesimpulan}

Berdasarkan tujuan penelitian ini, maka dapat disimpulkan bahwa kuantitas air destilasi yang dihasilkan pada alat penelitian penulis mulai dari jam 07:00 sampai jam 16:00 selama 8 hari didapat kuantitas air destilasi yang dihasilkan sebesar $2578 \mathrm{ml}$. Kualitas air tawar yang dihasilkan dari alat destilasi mencangkup Kekeruhan, warna, zat padat terlarut, suhu, rasa, dan bau telah memenuhi syarat untuk digunakan oleh masyarakat dalam kehidupan sehari-hari berdasarkan peraturan menteri kesehatan republik indonesia nomor 32 tahun 2017 tentang standar baku mutu kesehatan lingkungan dan persyaratan kesehatan air untuk keperluan higiene sanitasi.

\section{Referensi}

[1] Wahyudi, J., 2019. Uji Eksperimen estilasi Air Laut Dengan Variasi Sudut Kemiringan. Jurnal Energi. Vol. 9 No. 2. hal 1-6.

[2] Putra, R. A; Pauzi, G.A; Surtono, A., 2018. Rancang Bangun Alat Destilasi Air Laut dengan Metode Ketinggian Permukaan Air Selalu Sama Menggunakan Energi Matahari. Jurnal Teori dan Aplikasi Fisika, Vol. 06, No. 01, hal 101-108.

[3] Alamsyah, S., 2007. Merakit Sendiri Alat Penjernih Air Untuk Rumah Tangga. Jakarta: PT. Kawan Pustaka

[4] Nanawi, G., 2001. Kualias Air dan Kegunaannya di Bidang Pertanian. Jakarta: Direktorat Pendidikan Menengah Kejuruan.

[5] Mulyanef., Burmawi., \& muslimin., 2014. Pengolahan air laut menjadi air bersih dan garam dengan destilasi tenaga surya. Jurnal teknik mesin vol.4, No.1, hal 25 - 29,

[6] Astuti, U, P., 2016. Atap desalinasi sebagai solusi pemenuhan kebutuhan air bersih di daerah pesisir. Journal of Research and Technology, Vol. 2 No. 2, hal 57-63.

[7] Puja, I. G. K. \& Sambada, R., 2012 Unjuk Kerja Destilasi Air Energi
Surya. Jurnal Energi dan Manufaktur Vol.5, No.1, hal 82-88.

[8] Hidayat, R. R., 2011. Rancang Bangun Alat Pemisah Garam dan Air Tawar Menggunakan Energi Matahari, Skripsi.

[9] Ismail, N. R., 2010 Pengaruh Bentuk Cover Terhadap Produktifitas dan Efisiensi Solat Still. Jurnal. Teknologi., Vol. 3, No. 1, pp. 7074 .

[10] Dewantara, I.G.Y, Suyitno, B.M, Lesmana, I.G.E. 2018. Desalinasi air laut berbasis energi sirya sebagai alternatif penyediaan air bersih. Jurnal Teknik mesin (JTM) Vol 07, No. 1, hal 1-4

[11] Kumar B.S., Sanjay K., Jayaprakash, R. 2008. Performance analysis of a "V" type solar still using a charcoal absorber and a boosting mirror. 217230

[12] Mulyanef, Saputra, R.A, Kaidir \& Duskiardi. 2015. Kaji Eksperimental Alat Pengolahan Air Laut Menggunakan Energi Surya Untuk Memproduksi Garam Dan Air Tawar. Proceeding Seminar Nasional Tahunan Teknik Mesin XIV (SNTTM XIV). Banjarmasin, 7-8 Oktober. Hal. 1-5

[13] Ali, M \& Waliden, K., 2019. Alat Destilasi Air Laut Berbasis Energi Surya dan energi Elektrik sebagai Alternatif Penyediaan Air Bersih dan Garam. Seminar Sains dan Teknologi Kelautan(SENSISTEK) Fakultas Teknik UNHAS Gowa 1 Oktober. Hal 42-47

[14] Peraturan Menteri Kesehatan R.I Nomor 492/MENKES/PER/IV/2010. Tentang Persyaratan Kualitas Air Minum. Jakarta. 